\title{
PEMBELAJARAN KONTEKSTUAL AGAMA HINDU UNTUK MEMBANGUN GENERASI MUDA BERBUDI PEKERTI LUHUR
}

\author{
Ni Wayan S. Binawati ${ }^{1}$, I Wayan Rasna ${ }^{2}$ \\ ${ }^{1}$ Institut Hindu Dharma Negeri Denpasar, Indonesia, ${ }^{2} J u r u s a n$ Pendidikan Bahasa dan \\ Sastra Indonesia, Universitas Pendidikan Ganesha Singaraja, Indonesia. \\ e-mail: wsbinawati@yahoo.com
}

\begin{abstract}
Abstrak
Penelitian ini bertujuan untuk mengkaji 1) realitas pembelajaran kontekstual agama Hindu dan 2) faktor-faktor yang menjadi kendala pembelajaran kontekstual agama Hindu. Lokasi penelitian ini ialah SMA Lab. Undiksha dengan jumlah sampel 90 orang. Sampel ditarik dengan teknik purposive quota sampling. Data realitas pembelajaran dikumpulkan dengan metode observasi, wawancara mendalam dan data faktor kendala pembelajaran kontekstual dikumpulkan dengan observasi dan wawancara. Data yang terkumpul dianalisis secara deskriptif.

Hasil penelitian menunjukkan bahwa: 1) realitas pembelajaran kontekstual agama Hindu berjalan dengan baik sesuai perolehan skor 82 (baik) dan faktor-faktor yang menjadi kendala pembelajaran kontekstual agama Hindu adalah: 1) kurangnya langkah-langkah yang membantu anak untuk berpikir kritis, kreatif, dan 2) kurangnya upaya belajar melalui kerjasama. Melalui kerjasama mereka menyemai toleransi dan perasaan mengasihi. Sehungan dengan hal ini, disarankan agar guru memberikan kesempatan anak untuk berpikir dalam tingkatan yang lebih tinggi dan membangun hubungan suasana belajar bekerjasama dalam rangka persemaian toleransi dan perasaan mengasihi.
\end{abstract}

Kata Kunci : Pembelajaran Kontekstual, Budi Pekerti.

\begin{abstract}
This study aims at investigating: 1) the nature of the contextual instruction of Hindu religion and 2) the factors that become the obstacles for the contextual instruction of Hindu religion. The setting of the study was SMA Lab Undiksha, with the total number of samples 90 people. The sample of the study were determined by using purposive quota sampling technique. The data concerning the nature of the contextual instruction of Hindu religion were collected through observation and interview. The collected data were then descriptively analyzed.

The result of the study shows that: 1) the nature of the contextual instruction of Hindu religion ran well with the score 82 (good) and the factors causing obstacles for contextual instruction of Hindu religion were: 1 ) the lack of the instructional steps helping the students to think critically and creatively, and 2) the lack of cooperative studying attempts. Through cooperation, the students develop their tolerance and respect to each other. In this respect, it is suggested that the teacher should give the chance to the students to involve in higherorder thinking and to develop cooperative instructional atmosphere in attempting to increase the students' tolerance and feeling of respect.
\end{abstract}

Key words : Contextual Instruction, Characters. 


\section{PENDAHULUAN}

Pendidikan yang baik adalah pendidikan yang tidak hanya mempersiapkan para siswanya untuk suatu profesi atau jabatan, tetapi untuk menyelesaikan masalah-masalah yang dihadapinya dalam kehidupan sehari-hari (Trianto, 2008:3). Hal ini menunjukkan pendidikan tidak hanya mencakup pengembangan intelektualitas saja, akan tetapi lebih ditekankan pada proses pembinaan kepribadian anak didik secara menyeluruh sehingga anak menjadi lebih dewasa (Sagala, 2008:3).

Proses pembinaan kepribadian anak didik secara menyeluruh ini mengindikasikan adanya peran penggiat pendidikan, khususnya guru dan dosen sebagai pelaku perubahan (agent of change). Anak didik memiliki potensi gandrung dan kemampuan yang merupakan benih kodrati untuk ditumbuhkembangkan tanpa henti. Maksudnya, pendidikan seyogyanya menyirami benih kodrati ini hingga tumbuh subur dan berbuah (Alwasilah, 2011:17). Hal ini menggambarkan bahwa pentingnya pengetahuan terletak pada kegunaannya (Johnson, 2011). Semua masyarakat menginginkan generasi yang baik, tetapi kadang-kadang tidak sesuai dengan kenyataan (Ruhaliah, 2011:3) Nilai-nilai kesantunan dan budi pekerti luhur yang diwariskan nenek moyang juga semakin memudar (Nugrahani, 2011:2). Lebih lanjut Nugrahani menyebutkan bahwa pemimpin bangsa yang seharusnya menjadi contoh juga tidak lagi mampu menempatkan dirinya dengan benar. Selaras dengan hal ini kurangnya wibawa guru merupakan faktor penghambat untuk menjadikan diri guru sebagai teladan (Afit, 2001). Sebagian besar siswa tidak sabar, mudah bertengkar, tidak mengerjakan PR, suka menyontek, suka menulisi bangku, terlambat, dan membolos (Simanjuntak, 1989). Untuk itulah perlu diberikan pendidikan budi pekerti (Hadi Winarto, 2009:1205, Afit. 2001, dan Simanjuntak, 1989). Oleh karena itu diperlukan pendidikan budi pekerti.
Kurangnya pengetahuan dan keterampilan guru dalam melakukan pendidikan budi pekerti, pemahaman sempit tentang budi pekerti, kurangnya wibawa guru merupakan faktor penghambat untuk menjadikan diri guru sebagai teladan (Afit:2001). Di luar itu, siswa juga suka merokok di sekolah dan berkelahi (Hadiwinarto, 2009:1204). Hal ini sudah merupakan penyimpangan moral. Penyimpangan moral tidak hanya menjadi tanggung jawab pendidik agama, tetapi tanggung jawab semua pendidik. Sebab hasil pendidikan budi pekerti merupakan bagian integral dari hasil pendidikan pada umumnya. Karena pendidikan budi pekerti mencakup aspek kognitif (pemahaman pengetahuan), aspek afektif (emosi dan perasaan) dan aspek motorik (perilaku) (Hadiwinarto, 2009:1205), afif, 2001; dan Simanjuntak, 1989). Budi pekerti itu adalah akhlak (moral) yakni sebuah sistem yang lengkap yang terdiri dari karakteristik atau perilaku yang membuat seseorang menjadi istimewa (Hadiwinarto, 2009:1209). Keistimewaan ini disebabkan oleh 1) pendidikan budi pekerti berkaitan dengan semua hasil belajar, 2) penanaman nilai budi pekerti terintegrasi ke dalam proses pembelajaran semua mata pelajaran, terutama mata pelajaran agama dan PPKn (Mulyana, 2004). Budi pekerti sangat erat kaitannya dengan nilai-nilai moral ataupun nilai-nilai sosial tersebut digunakan untuk mencapai kehidupan manusia yang harmonis (Kniker, 1977 dan Raven, 1977). $\mathrm{Hal}$ ini menunjukkan bahwa nilai moral berguna bagi kehidupan masyarakat yang harmonis (Frondizi, 2001). Nilai moral adalah keputusan etik yang digunakan memulai arah atau aktivitas seseorang benar sekali atau baik sekali. Berkaitan dengan hal ini, maka nilai-nilai budi pekerti perlu dideskripsikan seperti tertuang berikut ini : 1)Meyakini adanya Ida Sang Hyang Widhi Wasa dan selalu menjalankan dharma yang ditandai oleh sikap dan perilaku yang mencerminkan keyakinan dan kepercayaan 
terhadap Tuhan Yang Maha Esa; 2) menaati ajaran agama yang tercermin melalui sikap dan perilaku yang mencerminkan kepatuhan, tidak ingkar dan taat menjalankan perintah dan menjauhi larangan agama; 3) memiliki dan mengembangkan sikap toleransi berupa sikap dan perilaku yang mencerminkan toleransi dan penghargaan terhadap pendapat, gagasan, tingkah laku orang lain baik yang sependapat maupun yang tidak sependapat dengan dirinya; 4) memiliki rasa menghargai diri sendiri melalui sikap dan perilaku yang mencerminkan toleransi dan penghargaan terhadap pendapat, gagasan, tingkah laku orang lain baik yang sependapat maupun yang tidak sependapat dengan dirinya; 5) tumbuhnya disiplin diri berupa sikap dan perilaku sebagai cerminan dan ketaatan, kepatuhan, ketertiban, kesetiaan, ketelitian, dan keteraturan perilaku sesorang terhadap norma dan aturan yang berlaku; 6) mengembangkan etos kerja atau belajar bersikap dan berperilaku yang mencerminkan dan semangat, kecintaan, kedisiplinan, kepatuhan, loyalitas, dan penerimaan terhadap kemajuan hasil kerja/belajar; 7) memiliki rasa tanggung jawab yang terlihat dari sikap dan perilaku seseorang untuk melaksanakan tugas dan kewajibannya, yang seharusnya ia lakukan terhadap diri sendiri, masyarakat, lingkungan (alam dan sosial) negara dan Tuhan Yang Maha Esa; 8) memiliki rasa keterbukaan yang ditunjukkan oleh sikap dan perilakunya yang mencerminkan adanya keterusterangan terhadap apa yang dipikirkan, diinginkan, diketahui, dan kesediaan menerima saran dan kritik dari orang lain; 9) mampu mengendalikan diri berupa kemampuan seseorang untuk dapat mengatur dirinya sendiri berkenaan dengan kemampuan, nafsu, ambisi, keinginan, dalam memenuhi rasa kepuasan dan kebutuhan hidupnya; 10) mampu berfikir positif seperti terlihat pada sikap dan perilaku seseorang untuk dapat berfikir jernih, tidak buruk sangka, mendahulukan sisi positif suatu masalah; 11) mengembangkan potensi diri dalam wujud sikap dan perilaku seseorang untuk dapat membuat keputusan sesuai dengan kemampuannya mengenal bakat, minat, dan prestasi serta sadar akan keunikan dirinya sehingga dapat mewujudkan potensi diri yang sebenarnya; 12) menumbuhkan cinta kasih sayang dengan mencermati sikap dan perilaku seseorang yang mencerminkan adanya unsur memberi perhatian, perlindungan, penghormatan, tanggungjawab, dan pengorbanan terhadap orang yang dicintai dan dikasihi; 13) memiliki sikap kebersamaan dan gotong royong dengan indikator sikap dan perilaku seseorang yang mencerminkan adanya kesadaran dan kemauan untuk bersama-sama, saling bantu dan saling memberi tanpa pamerih; 14) memiliki rasa kesetiakawanan seperti terlihat pada sikap dan perilaku yang mencerminkan kepedulian kepada orang lain, keteguhan hati, rasa setia kawan, dan rasa cinta terhadap orang lain dan kelompoknya; 15) saling menghormati yang tercermin melalui sikap dan perilaku untuk menghargai dalam hubungan antarindividu dan kelompok berdasarkan norma dan tata cara yang berlaku; 16) memiliki tata krama dan sopan santun berupa sikap dan perilaku sopan santun dalam bertindak dan bertutur kata terhadap orang lain tanpa menyinggung/menyakiti serta menghargai tata cara yang berlaku sesuai dengan norma budaya dan adat istiadat; 17) memiliki rasa malu dengan sikap dan perilaku yang menunjukkan tidak enak hati, hina, rendah karena berbuat sesuatu yang tidak sesuai dengan hati nurani, norma dan aturan; dan 18) menumbuhkan kejujuran melalui sikap dan perilaku untuk bertindak dengan sesungguhnya dan apa adanya, tidak berbohong, tidak dibuat-buat, tidak ditambah dan tidak dikurangi, dan tidak menyembunyikan informasi.

Pembelajaran kontekstual menuntut adanya kebermaknaan yang diperoleh siswa dalam proses pembelajaran.

Atas dasar kegunaan/makna inilah pembelajaran kontekstual ini dipilih dan 
digunakan dalam pembelajaran agama Hindu. Penemuan ilmiah terbaru saat ini memberitahu bahwa justru hubungan antara bagian-bagiannya yaitu konteksnya yang memberikan makna. Lebih jauh lagi makna yang berasal dari hubungan itu membuat gabungan dari semua bagian itu melampaui sekedar jumlah dari bagian-bagiannya (Johnson, 2001:33). Tujuan utama seseorang, bukanlah mencari kesenangan maupun menghindari rasa sakit, tetapi untuk menemukan makna hakiki hidup Makna dapat ditemukan dengan tiga cara, yaitu : (1) melakukan tindakan, (2) menghayati sesuatu, dan (3) sikap kita menghadapi penderitaan. Karena makna masih bisa terdapat dalam penderitaan sekali pun (Frankl, 1984:133-134).Sehubungan dengan hal ini, ilmu saraf memastikan adanya kebutuhan otak untuk menemukan makna (Johnson, 2011:36). Begitu otak menemukan makna, struktur fisiknya berubah seiring dengan pembentukan hubungan saraf (Diamond \& Hapson, 1998 ; Greenfield, 1997) (Jensen, 2011:4-5). Hal ini menunjukkan bahwa proses belajar harus memungkinkan siswa memahami arti pelajaran yang mereka pelajari. Anak harus menjadikan ide-ide tersebut milik mereka, dan harus mengerti penerapannya dalam situasi kehidupan nyata (Whitehead,1967:2). $\mathrm{Hal}$ ini sejalan dengan Sagala yang menyebutkan bahwa pendekatan kontekstual merupakan konsep belajar yang membantu guru mengaitkan materi yang diajarkannnya dengan situasi dunia nyata (Sagala, 2008:87).

Ada tiga alasan digunakannya pendekatan kontekstual sebagai pilihan, yaitu : (1) sejauh ini pendidikan kita masih didominasi oleh pandangan bahwa pengetahuan sebagai perangkat fakta yang harus dihafal (2) melalui landasan filosofi kontruktivisme pendekatan kontekstual dipromosikan menjadi alternatif strategi belajar yang baru. Karenanya siswa diharapkan belajar melalui mengalami, bukan menghafal , dan (3) knowlegde is contructed by humans (Zahorik, 1995).
Ada lima elemen belajar kontruktivistik yang harus diperhatikan dalam pembelajaran kontekstual yaitu: (1) pengaktivan pengetahuan yang sudah ada (activating knowledge); (2) pemerolehan pengetahuan baru (acquiring knowledge) dengan cara mempelajari secara keseluruhan dulu kemudian memperhatikan detilnya. (3) pemahaman pengetahuan (understanding knowledge), yaitu dengan cara menyusun konsep sementara (hipotesis), melakukan sharing kepada orang lain agar dapat tanggapan (validasi), dan atas alasan tanggapan itu, konsep direvisi dan dikembangkan; (4) mempraktekkan pengetahuan dan pengalaman (applying knowledge); dan (5) melakukan refleksi (reflecting knowledge) terhadap strategi pengembangan pengetahuan (Zahorik, 1995:14-22)

Uraian di atas mengindikasikan bahwa otak anak pada dasarnya tidak seperti gelas kosong yang siap diisi air informasi yang berasal dari pikiran guru. Otak anak berisi pengetahuan yang dikontruksi anak sendiri (Karhami, 2002:159). Sayang sekali, masih ada guru yang memandang anak tidak memiliki pengetahuan materi yang diajarkan. Sehubungan dengan hal ini, dan hasil survei the Brirtish Council (Suhandi, U. Karhami SKA, Maskur, 2000) terhadap 192 guru SD diketahui bahwa $63,5 \%$ masih menganggap mengajar sebagai kegiatan menstransfer informasi dan hanya $5,2 \%$ yang menganggap mengajar sebagai menciptakan kondisi, sehingga peristiwa siswa belajar dapat berlangsung (Karhami, 2002:166).

Konsep yang menganggap mengajar sebagai mentransfer informasi sudah saatnya didisain ulang menjadi guru perlu menggeser peran siswa supaya lebih variatif dalam rentang peran sebagai konsumen. Kurangi peran siswa yang melulu hanya diposisikan sebagai konsumen yang lazim bercirikan buku halaman sekian, kerjakan, salin, dengarkan (Karhami, 2002:168). 


\section{METODE PENELITIAN}

Masalah yang dikaji dalam penelitian ini ialah 1) bagaimanakah realitas pembelajaran kontekstual agama Hindu dan 2) faktor-faktor apakah yang menjadi kendala pembelajaran kontekstual agama Hindu. Pemecahan masalah ini dilakukan dengan langkah sebagai berikut: (1) mengumpulkan data realitas pembelajaran kontekstual Agama Hindu; (2) menggali dan mengkaji faktor-faktor yang menjadi kendala pembelajaran kontekstual agama Hindu; (3) analisis masalah untuk menentukan langkah pemecahan; dan (4) penentuan langkah pemecahan masalah dengan jalan memberikan bantuan dan kesempatan anak berpikir kritis, kreatif, dan meningkatkan upaya belajar melalui kerja sama. Tujuan penelitian ini ialah mengkaji realisasi pembelajaran kontekstual agama Hindu, dan (2) mengkaji faktor-faktor yang menjadi kendala pembelajaran kontekstual agama Hindu.

Objek penelitian ini ialah pembelajaran kontekstual agama Hindu. Subjek penelitian siswa Kelas X SMA Lab Undiksha Singaraja sebanyak 90 orang yang diambil dengan teknik purposive quota sampling. Variabel penelitian ini ialah pembelajaran kontekstual agama Hindu dan faktor kendala pembelajaran kontekstual agama Hindu. Data pembelajaran kontekstual dirinci menjadi : (1) data analisis aspek guru dan (2) data analisis aspek siswa.

1) Analisis Aspek Guru

Data ini dikumpulkan dengan observasi terhadap RPP (rencana pelaksanaan pembelajaran) dan kesesuaiannya dengan pelaksanaannya di kelas. Contoh format analisis observasi seperti terlihat pada tabel 01 berikut ini.

Tabel 01: Format Analisis Observasi Kesesuaian Tujuan Kurikulum dengan Realisasi di Kelas.

\begin{tabular}{|c|c|c|c|c|}
\hline No & Aspek & Deskriptor & Skor & Ket \\
\hline \multirow[t]{5}{*}{1.} & \multirow{5}{*}{$\begin{array}{l}\text { Kesesuaian } \\
\text { tujuan kurikulum } \\
\text { dengan realisasi. }\end{array}$} & $\begin{array}{l}\text { Semua tujuan kurikulum sangat sesuai } \\
\text { dengan realisasi (86-100\%) }\end{array}$ & 4 & 4 = Sangat baik \\
\hline & & $\begin{array}{l}\text { Sedikit tujuan yang tak sesuai realisasi. } \\
(71-85 \%)\end{array}$ & 3 & $3=$ baik \\
\hline & & $\begin{array}{l}\text { Sebagian tujuan yang sesuai realisasi } \\
(56-70 \%)\end{array}$ & 2 & 2 = cukup \\
\hline & & $\begin{array}{l}\text { Sedikit tujuan yang sesuai realisasi }(40 \\
55 \%)\end{array}$ & 1 & $1=$ kurang \\
\hline & & $\begin{array}{l}\text { Tak ada tujuan yang sesuai realisasi } \\
(<40 \%)\end{array}$ & 0 & $0=$ sangat kurang \\
\hline
\end{tabular}

Semua item observasi untuk analisis aspek guru berjumlah 25. Dengan demikian apabila semua item dilakukan dengan sempurna maka skor maksimal ideal $(\mathrm{SMI})=$ 100. Wawancara dilakukan terhadap guru untuk mendapatkan data kendala pembelajaran kontekstual agama Hindu. Di samping metode wawancara, kuesioner, juga digunakan untuk mengumpulkan data pandangan siswa terhadap mata pelajaran agama dibandingkan mata pelajaran IPA dan bahasa Inggris. Misalnya aspek kesesuaian tujuan kurikulum dengan realisasi materi kelas XI semester ganjil pada pertemuan pertama dengan standar kompetensi (SK) : memahami Hukum Karmapala dan Punarbawa dengan Kompetensi Dasar (KD) : 1) menjelaskan pengertian Hukum Karmapala dan Punarbawa; 2) menjelaskan bagian-bagian Hukum Karmapala dan 3) menjelaskan dengan contoh nyata kaitan karma dengan pahala sebagai dasar pendidikan budi pekerti luhur. Kompetensi dasar ini melahirkan indikator : 1) menjelaskan hukum karmapala dan punarbawa; 2) menjelaskan 
bagian-bagian hukum karmapala dan 3) menjelaskan dengan contoh nyata kaitan karma dengan pahala. Untuk membangun generasi muda berbudi pekerti luhur, seperti a tidak punya uang, sehingga tidak bisa memenuhi permintaan anaknya. Permintaan anak yang tak dapat dipenuhi oleh orang tuanya telah menjadi sebab keluarnya katakata sang anak sebagai berikut : ya sekarang tidak diberi, nanti kalau anak dan sepeda motor ini hancur baru akan diberi. Satu setengah bulan kemudian anak ini tabrakan yang mengakibatkan sepeda motor dan anak ini juga hancur sehingga anak ini ofname di rumah sakit selama 6 bulan. Pengalaman yang dapat dipetik dari kisah nyata ini adalah jangan mengeluarkan ucapan/kata-kata yang menimbulkan bahaya atau kata-kata yang mengandung bahaya (ujar hala). Hal ini sesuai dengan Kakawin Nitisastra V.3 yang menyatakan wasita nimittanta manemu duka (oleh karena perkataan engkau mendapatkan kesusahan) (Wiana, 2002;75). Contoh nyata ini merupakan prarabda karmapala yang dapat digunakan sebagai tuntutan untuk membangun generasi muda berbudi pekerti luhur.

2) Analisis Aspek Siswa

Analisis aspek siswa meliputi kognitif, afektif dan psikomotor. Aspek kognitif dikumpulkan dengan metode tes seperti contoh berikut.

IImu pengetahuan yang mempelajari jiwa remaja dan permasalahannya, termuat dalam kitab Ajur Weda pada bagian
(A) Salya
(B) Wajikaranatantra
(C) Saritana
(D) Sutrathana
(E) Siddistana

Jumlah soal untuk aspek kognitif sebanyak 25 dengan skor 4 untuk jawaban benar dan 0 untuk jawaban salah. Jadi jika semua jawaban yang diberikan benar, maka akan diperoleh skor maksimal 100 dan jika semuanya salah akan diperoleh skor $=0$

Aspek afektif dikumpulkan dengan dua cara, yaitu tes untuk mengumpulkan aspek kejadian berikut ini. Seorang pemuda yang juga seorang pelajar meminta sepeda motor baru kepada orang tuanya yang kebetulan saat itu orang tuany afektif yang berhubungan dengan teori perilaku seperti contoh berikut.

Dalam hidup ini hendaknya kita menjaga kerukunan dan keharmonisan antarasesama manusia dengan tidak saling iri hati seperti kecuali.
(A) iklas melepas jabatan rangkap
(B) merasakan penderitaan orang lain
(C) menahan rasa amarah.
(D) belas kasihan
(E) kecewa

Tes ini berjumlah 25 buah dengan skor 4 untuk jawaban benar dan 0 untuk jawaban salah. Jadi rentang nilai antara 0 100. Untuk praktek perilaku data dikumpulkan dengan observasi. Contoh materi dengan Standar Kompetensi (SK) memahami ajaran Tat Twam Asi sebagai landasan etika dan moral dengan Kompetensi Dasar (KD) menjelaskan pengertian tat twam asi dan pentingnya tat twam asi dalam kehidupan. Tat twam asi dalam kehidupan identik dengan perikemanusiaan dalam Pancasila. Sehubungan dengan hal ini, perilaku dasar yang diobservasi adalah suka menolong, hidup rukun, rasa kebersamaan, merasa senasib sepenanggungan seperti dijelaskan dalam Whraspati Tattwa 26 yang berbunyi, Eka ngarannya angraksa acara rahayu, yang artinya untuk dapat menjadi manusia yang berbudi baik (luhur) manusia hendaknya menjadikan hubungan yang harmonis dengan sesama makhluk Tuhan dengan merealisasikan ajaran tat twam asi.

Data kendala pembelajaran agama Hindu dikumpulkan dengan metode observasi dengan format sebagai berikut. 


\begin{tabular}{|c|c|c|c|c|}
\hline No & Aspek & Deskriptor & Skor & Ket \\
\hline 1. & $\begin{array}{l}\text { Keterkaitan } \\
\text { bermakna. }\end{array}$ & $\begin{array}{l}\text { Kaitan tugas sekolah dengan kehidupan } \\
\text { sehari-hari } \\
\text { a. sangat tak bermakna }(86-100 \%) \\
\text { b. Bermakna }(71-85 \%) \\
\text { c. Biasa }(56-70 \%) \\
\text { d. Kurang bermakna }(40-55 \%) \\
\text { e. Tak bermakna }(<40 \%)\end{array}$ & $\begin{array}{l}4 \\
3 \\
2 \\
1 \\
0\end{array}$ & $\begin{aligned} 4 & =\text { sangat baik, } \\
3 & =\text { baik, } \\
2 & =\text { cukup } \\
1 & =\text { kurang, } \\
0 & =\text { sangat } \\
& \text { kurang }\end{aligned}$ \\
\hline 2. & $\begin{array}{l}\text { Pembelajaran } \\
\text { mandiri. }\end{array}$ & $\begin{array}{l}\text { Kebebasan siswa menemukan kehidupan } \\
\text { akademik dengan kehidupan sehari-hari. } \\
\text { a. sangat tak bebas } \\
\text { b. bebas } \\
\text { c. biasa } \\
\text { d. kurang bebas } \\
\text { e. tak bebas }\end{array}$ & $\begin{array}{l}4 \\
3 \\
2 \\
1 \\
0\end{array}$ & \\
\hline 3. & Kerjasama & $\begin{array}{l}\text { Pemecahan masalah dilakukan kelompok } \\
\text { kecil dengan kerjasama yang } \\
\text { a. sangat tidak kompak } \\
\text { b. tidak kompak } \\
\text { c. biasa } \\
\text { d. kurang kompak } \\
\text { e. kompak } \\
\text { Dialog sebagai dasar kerja sama dalam } \\
\text { pemecahan masalah berlangsung } \\
\text { a. sangat tak lancar. } \\
\text { b. Tidak lancar } \\
\text { c. biasa } \\
\text { d. tersendat-sendat } \\
\text { e. berjalan }\end{array}$ & $\begin{array}{l}4 \\
3 \\
2 \\
1 \\
0\end{array}$ & \\
\hline 4. & $\begin{array}{l}\text { Berpikir kritis dan } \\
\text { kreatif. }\end{array}$ & $\begin{array}{l}\text { Kendala yang dihadapi dalam memberikan } \\
\text { kesempatan berpikir kritis ialah kesiapan } \\
\text { emosi guru : } \\
\text { a. sangat tak siap } \\
\text { b. tidak siap } \\
\text { c. biasa } \\
\text { d. kurang siap } \\
\text { e. siap }\end{array}$ & $\begin{array}{l}4 \\
3 \\
2 \\
1 \\
0\end{array}$ & \\
\hline
\end{tabular}

Jumlah soal observasi sebanyak 25. Jika kedua puluh lima soal itu mendapat nilai 4 maka total sekor yang diperoleh sebesar 100. Apabila kedua puluh lima soal itu mendapat nilai 0 , maka nilai yang diperoleh adalah 0 .

\section{METODE PENGOLAHAN DATA}

Data yang terkumpul diolah secara deskriptif dengan langkah sebagai berikut

1. Pengecekan data

Data yang diperoleh perlu dicek kebenarannya untuk menjaga kevalidan data. Pengecekan dilakukan secara kolaborasi bersama tim. Hal ini 
dilakukan untuk menjadikan dan menjaga kevalidan data.

2. Tabulasi

Penabulasian dilakukan untuk memudahkan analisis data. Data yang telah ditabulasi dianalisis memakai prinsip analisis deskriptif.
3. Analisis Data

Data yang telah ditabulasi, lalu dibuatkan pedoman konversi berupa kriteria yang digunakan untuk menentukan kualitas kendala pembelajaran kontekstual seperti tabel 02 berikut

Tabel 02 : Kriterium Kendala Pembelajaran Kontekstual

\begin{tabular}{|c|c|c|}
\hline \hline NO & Skor & Predikal \\
\hline 1 & $85-100 \%$ & Sangat Tinggi \\
\hline 2 & $70-84 \%$ & Tinggi \\
\hline 3 & $55-69 \%$ & Cukup \\
\hline 4 & $45-54 \%$ & Kurang \\
\hline 5 & $10-44 \%$ & Rendah \\
\hline
\end{tabular}

(Diadopsi dari Pedoman Studi Program Sarjana dan Diploma Undiksha, 2011:38)

\section{HASIL DAN PEMBAHASAN} Hasil Penelitian

\section{A. Realitas Pembelajaran Kontekstual} Agama Hindu.

Realitas pembelajaran kontekstual agama Hindu berjalan dengan baik. Hal ini ditunjukkan oleh data analisis aspek guru sesuai perolehan skor yaitu 82 (86\%) (baik). Realitas ini dimungkinkan karena : 1) guruguru yang mengajarkan agama Hindu di SMA Lab Undiksha adalah guru-guru tersertifikasi, 2) sebagai guru tersertifikasi mereka sudah mendapatkan model pembelajaran inovatif yang memungkinkan pembelajaran kontekstual dilakukan. Hal ini menunjukkan bahwa kesesuaian tujuan kurikulum dengan realisasi di kelas berjalan dengan baik untuk aspek kognitif. Karena sasaran yang diutamakan adalah kelulusan dalam ujian nasional. Dilihat dari keterkaitannya dengan pembangunan generasi muda berbudi pekerti luhur, terutama terkait dengan 18 nilai budi pekerti masih banyak yang perlu disempurnakan antara lain melalui pemberian contoh faktual berupa pengungkapan pengalaman hidup masih sangat kurang (35\%). Pada hal pengungkapan pengalaman hidup (faktual) dapat membuat orang lain untuk bercermin pada pengalaman orang lain, seperti contoh berikut, seorang gadis cantik yang sudah dewasa dan sudah bekerja menelpon orang tuanya untuk minta ijin menikah karena sudah hamil. Ibunya setuju, namun bapaknya malah berkata: "daripada melihat kamu menikah, lebih baik bapak melihat kamu mati”. Kata-kata itu sungguh menyakitkan hati gadis itu. Oleh karena, gadis itu sudah mengandung, tidak ada pilihan lain, kecuali menikah, 2 hari sebelum hari $\mathrm{H}$, gadis ini akan dipinang pihak lakilaki, untuk acara ini, si gadis harus pulang kampung. Di jalan by pass, gadis ini mengalami kecelakaan. Awalnya gadis ini bisa bangun, tetapi malah ditabrak lagi dari belakang oleh sebuah truk, dan perutnya terlindas. Nyawa gadis ini tidak terselamatkan. Keluarganya terkejut, bapaknya menyesal telah berkata/mengeluarkan kata-kata yang menimbulkan bahaya (ujar hala). Hal ini merupakan fakta penting dalam hidup ini, agar berhati-hati bicara, sehingga kata-kata yang keluar tidak menimbulkan bahaya. Ini adalah salah satu tuntunan pembinaan generasi muda berbudi pekerti luhur melalui ucapan yang terjaga (wacika).

\section{B. Faktor-Faktor yang Menjadi Pembelajaran Kontekstual Agama Hindu.}

Secara yuridis formal, kedudukan mata pelajaran agama Hindu sama dengan 
kedudukan mata pelajaran lainnya seperti : Kimia, Fisika, Matematika, Bahasa Inggris maupun yang lainnya. Akan tetapi, secara realitas ada anggapan bahwa pelajaran Sains dan pelajaran Bahasa Inggris mendapat tempat tersendiri baik di mata siswa maupun orang tua. Tempat ini sedikit menggeser proses pelajaran agama Hindu ke posisi lebih di bawah dibandingkan dengan Sains dan bahasa Inggris. Dampaknya perhatian siswa terhadap mata pelajaran agama Hindu tidak sebesar mata pelajaran sains dan bahasa Inggris. $85 \%$ siswa beranggapan bahwa bahasa Inggris dan Sains lebih penting daripada mata pelajaran agama Hindu. Hal ini menjadi salah satu sebab realisasi pembelajaran kontekstual menjadi terkendala, di samping kendala lainnya, seperti $85 \%$ sulit belajar berkelompok, pada tahap awal $80 \%$ siswa belum mau berbicara dan $85 \%$ siswa tidak banyak merespon.

Dari sudut pandang guru, ditemukan bahwa $10 \%$ responden menyatakan kurangnya langkah-langkah yang dapat membantu siswa untuk berpikir kritis, kreatif dan kurangnya upaya pembinaan belajar melalui kerjasama. Di samping itu $60 \%$ responden menyatakan bahwa, tugas yang diberikan belum terkait dengan kehidupan sehari-hari sehingga bermakna baginya.

Pembelajaran mandiri telah diupayakan oleh guru. Hal ini merupakan langkah penting dalam pembelajaran kontekstual. Karenanya harus dilanjutkan. Namun, hal ini saja belum cukup. Sebab, pembelajaran mandiri itu harus diupayakan sebagai kehidupan akademik dalam kehidupan sehari-hari

\section{PEMBAHASAN}

Realitas pembelajaran agama Hindu menunjukkan hasil baik dengan perolehan skor 82. Meskipun masih terdapat kelemahan yang harus diperperbaiki. Kelemahan itu ialah belum adanya pemanfaatan kondisi lingkungan, terutama pengaitan antara materi pelajaran dengan pengungkapan pengalaman hidup. Pada hal pengungkapan pengalaman hidup ini merupakan faktor penting dalam membangun genarasi muda berbudi pekerti luhur. Sebab, pengungkapan pengalaman hidup dapat merupakan sebuah rim yang dapat mengontrol perilaku seseorang. Contoh pengungkapan pengalaman hidup.

Contoh 1: Seorang siswa mengejek temannya yang berjalan memakai tongkat akibat kecelakaan. Saat temannya duduk, tongkat temannya diambil, kemudian dia sendiri memakai tongkat yang mengalami kecelakaan sambil tertawa. Dua minggu kemudian, dia sendiri mengalami musibah dan ia pun memakai tongkat. Setelah peristiwa ini, siswa itu sadar bahwa perbuatannya melanggar hukum karma.

Contoh 2: Seorang mahasiswa pada saat dibuatkan otonan (ritual hari kelahiran) oleh orang tuanya, dinasehati agar tidak bepergian jauh pada hari itu. Namun mahasiswa itu, tidak menghiraukan nasehat orang tua, bahkan ia pergi dengan penuh emosi sambil mengendarai sepeda motor. Akibatnya mahasiswa itu kecelakaan. Setelah itu terjadi, baru ia sadar bahwa ia sadar sikapnya salah, tidak mengikuti nasehat orang tua (desa abimana).

Pengungkapan pengalaman hidup seperti inilah yang merupakan jantung pembelajaran kontekstual agama Hindu dalam membangun generasi muda berbudi pekerti luhur. Sebab pengungkapan pengalaman hidup ini bukan saja relevan dengan teori pembelajaran konstekstual, juga pengalaman hidup ini bermakna sebagai penuntun perilaku. Kebermaknaan pemanfaatan kondisi lingkungan dalam pembelajaran konstekstual Agama Hindu untuk membangun generasi muda berbudi pekerti luhur berbeda dengan 
kebermaknaan pemanfaatan kondisi lingkungan dalam pembelajaran konstekstual yang hanya mencakup aspek kognitifnya. Pembelajaran kontekstual yang ada sekarang sangat mengutamakan aspek kognitif dibandingkan afektif dan psikomotor. Kurangnya keseimbangan inilah yang menjadi faktor utama degradasi moral secara afektif dan banyaknya pengangguran intelek secara psikomotor. Kebermaknaan yang diperlukan di sini bentuknya dengan mengubah perilaku orang yang negatif menjadi positif. Ini persoalan utamanya. Persoalan ini akan terjawab manakala orang takut berbuat salah dan selalu memedomani aturan, norma dalam perilakunya. Untuk hal inilah diperlukan pengungkapan pengalaman hidup seperti dicontohkan di atas sebagai salah satu tuntunan yang tentunya harus dilakukan pembinaan secara kontinu sejak kecil.

Pemanfaatan kondisi lingkungan, terutama faktor pengungkapan pengalaman hidup belum banyak disampaikan. Padahal pengungkapan pengalaman hidup merupakan faktor penting dalam membangun generasi berbudi pekerti luhur.

Hal ini menunjukkan bahwa kemampuan guru agama Hindu SMA Lab Undiksa dalam melakukan pembelajaran kontekstual tergolong baik secara kognitif. Hal ini tentu tidak terlalu tersulit untuk dipahami. Sebab 1) guru-guru SMA Lab Undiksha adalah guru-guru pilihan, 2) mereka guru-guru senior di bidangnya, 3) guru-guru di sini adalah guru yang rajin dan tekun untuk selalu melakukan inovasi dan 4) mereka adalah guru-guru yang sudah tersertifikasi. Karena itu wajar kalau mereka mampu mengemban tugas.

Kedua di balik keberhasilan itu masih terdapat adanya faktor yang menjadi kendala pelaksanaan pembelajaran kontekstual secara utuh. Secara teoritis, pembelajaran kontekstual terdiri atas delapan komponen : 1) membuat keterkaitan bermakna, 2) pembelajaran mandiri, 3) melakukan pekerjaan berarti, 4) bekerja sama, 5) berpikir kritis dan kreatif, 6) membantu individu untuk tumbuh dan berkembang, 7) mencapai standar yang tinggi, dan 8) menggunakan penilaian autentik (Johnson, 2011 : 15).

Di antara delapan komponen ini, yang masih menjadi kendala adalah komponen 1). yaitu membuat keterkaitan bermakna. Kendala ini terjadi, karena guru masih berorientasi kepada buku secara teoritis, dan belum banyak mengaitkannya dengan lingkungan nyata berupa pengungkapan pengalaman hidup 2). Kurangnya upaya belajar melalui kerjasama, seperti yang dipersyaratkan pada komponen, 3), yaitu bekerjasama. Melalui kerja sama mereka mengenali toleransi dan perasaan mengasihi. Di sinilah letak salah satu kekuatan pembelajaran kontekstual agama Hindu. Justru karena kekuatannya inilah pembelajaran kontekstual agama Hindu harus dilakukan.

Kendala yang ketiga adalah kurangnya langkah yang dilakukan oleh guru untuk membantu anak berpikir kritis dan kreatif. Pada posisi seperti ini diperlukan keterampilan dan kemampuan guru menjaga emosi tidak cepat marah apabila anak bertanya. Karena hal ini akan mematikan kreativitas anak, sehingga suasana kelas menjadi tidak hidup. Akibatnya, anak-anak yang lain menjadi takut untuk berpikir kritis. Meskipun hal ini tidak banyak terjadi, tetapi bukan berarti keadaan ini boleh dibiarkan dalam membimbing siswanya menjadi pemikir kritis dan kreatif. Oleh karena itu, Jensen (2011:46) menyebutkan bersabarlah terhadap pemelajar yang berpikir kritis dan kreatif, serta hargai perbedaan dan apresiasilah keunikan setiap pemelajar.

Pada pikiran kritis dan kreatif itu akan terjadi pertanyaan-pertanyaan rasional yang dapat membuat guru kebingungan. Pada saat ini guru harus juga kritis dan kreatif menghadapi pertanyaan-pertanyaan rasional itu sehingga tidak membuat guru kebingungan, dapat menyelesaikan masalah dengan baik, tanpa harus bersitegang dan emosi. Jika ini dapat dilalui niscaya guru ini 
bukan hanya dipuji, dan digugu, tetapi juga akan diteladani. Inilah yang ditunggutunggu dalam rangka mmebangun generasi muda berbudi pekerti luhur.

\section{SIMPULAN DAN SARAN}

Berdasar kepada uraian rumusan masalah di depan, simpulan penelitian ini ialah :

1. Realitas pembelajaran kontekstual agama Hindu benjalan dengan baik sesuai perolehan skor 82 (baik), meskipun masih ada yang perlu dibina terutama pemanfaatan pengalaman hidup sebagai hal yang paling urgen dalam menuntun generasi muda menghindari perilaku negatif.

2. Faktor-faktor yang menjadi kendala pembelajaran kontekstual agama Hindu ialah 1) adanya anggapan pelajaran sains dan bahasa Inggris lebih dibandingkan mata pelajaran lainnya sehingga pelajaran ini mendapat tempat tersendiri dibandingkan dengan pelajaran lain, seperti agama Hindu baik di mata siswa maupun orang tua siswa . $85 \%$ siswa beranggapan bahwa sains dan bahasa asing seperti bahasa Inggris lebih penting daripada pelajaran lainnya, pada tahap awal $85 \%$ siswa mengalami kesulitan belajar kelompok. $80 \%$ siswa belum mau berbicara dan $85 \%$ siswa belum banyak merespon.

Dari sudut pandang guru ditemukan kurangnya langkah-langkah yang dapat membantu siswa berpikir kritis dak kreatif. Tugas yang diberikan kurang terkait dengan kehidupan sehari-hari yang bermakna.

\section{SARAN}

1. Pembelajaran kontekstual agama Hindu perlu ditingkatkan

2. Upayakan untuk menekan anggapan mata pelajaran bahasa asing dan sain lebih tinggi daripada mata pelajaran agama Hindu

3. Perlu diupayakan langkah-langkah yang dapat membantu anak untuk berpikir kritis dan kreatif dengan jalan menjaga kestabilan emosi manakala terdapat pikiran kritis dan rasional.

4. Upaya belajar melalui kerja sama perlu dioptimalkan. Sebab, melalui kerjasama, siswa menyemai toleransi dan perasaan mengasihi.

\section{Ucapan Terima Kasih}

Pada kesempatan ini tim peneliti menyampaikan ucapan terimakasih kepada :

1. Direktorat Peneliti dan Pengabdian Kepada Masyarakat Direktorat Jenderal Pendidikan Tinggi Kementerian Pendidikan dan Kebudayaan atas bantuan dananya

2. Lembaga Penelitian Undiksha yang telah mengkoordinasikan segala urusan administrasi

\section{DAFTAR PUSTAKA}

Affit, Zemzam. 2001. Pendidikan Budi Pekerti dalam Pelayanan Bimbingan Konseling di Sekolah "Makalah Konvensi Nasional XII II PBI. Bandung Lampung.

Alwarilah, Chaedar. 2011. Tujuh Ayat Pendidikan Kontekstual. Bandung. Kaifa

Diamond, M. \& Hopson, 1998, J. Magic Trees of the Mind: How to Nurture Your Child's Intelligence, New York : A Plume Book.

Frankl,V.E.1984. Man's Search for Meaning, New York: Simon \& Schuster.

Greenfield, S. 1997. The Human Brain: A Guided Tour, New York: Basic Books.

Jensen, Eric. 2011. Pembelajaran Berbasis Otak Paradigma Pengajaran Baru. Jakarta: PT. Indeks.

Johnson, Elaine B. 2011. Contextual Teaching \& Learning. Menjadikan Kegiatan Belajar Mengajar Mengasyikkan dan Bermakna. Bandung : Kaifa.

Karhami, S. Karim A. 2002. Mengubah Wawasan \& Peran Guru dalam Era Kesejagatan dalam Jurnal Pendidikan dan Kebudayaan. Maret 2002 Tahun ke-8, No.035 ISSN 0215-2673 
Kniker, C.R.1977. You and values Education. Columbus: Ohio Charles E. Merril Publishing Company.

Mulyana, Rohmat. 2004. Mengartikulasi Pendidikan Nilai : Bandung : Alfabeta.

Nugrahani, Farida.2011. Reaktualisasi Tembang Dolanan Jawa dalam Rangka Pembentukan Karakter Bangsa. Denpasar: Simposium Internasional.

Tim Revisi Buku Pedoman Studi: 2011. Pedoman Studi. Singaraja. Undiksha.

Raven, J. 1977. Education, Values and Society: The Objectives of Education and the Nature and Development of Competence. London: HK Lewis \& Co.Ltd.

Ruhaliah, 2011. Pendidikan Karakter dalam Peribahasa dan Permainan Anak Sunda. Denpasar : Simposium Internasional.

Sagala, Syaiful.2008. Konsep dan Makna Pembelajaran. Bandung : Alfabeta.
Simanjuntak, WBP. 1989. Usaha Budi Pekerti dalam Memperkuat Kepribadian di Sekolah. Laporan Penelitian. Jakarta: Puslit Balitbang.

Trianto. 2008. Mendesain Pembelajaran Kontekstual di Kelas. Surabaya: Cerdas Pustaka.

Whetehead, A.N. 1967. The Aims of Education (Tujuan Pendidikan) dalam The Aims of Education and Other Essays. (h.1-14). New York: Free Press.

Wiana, I Ketut. 2002. Veda Vakya Tuntunan Praktis Memahami Weda Jilid Pertama. Denpasar: PTBP.

Zahorik, John A. 1995. Contructivist Teaching (Fastback: 390). Bloomington, Indiana: Phi-Dekto Kappa Education Foundation.

Zuriah, Nurul.2011. Pendidikan Moral Budi Pekerti dalam Perspektif Perubahan. Jakarta: PT. Bumi Aksara. 